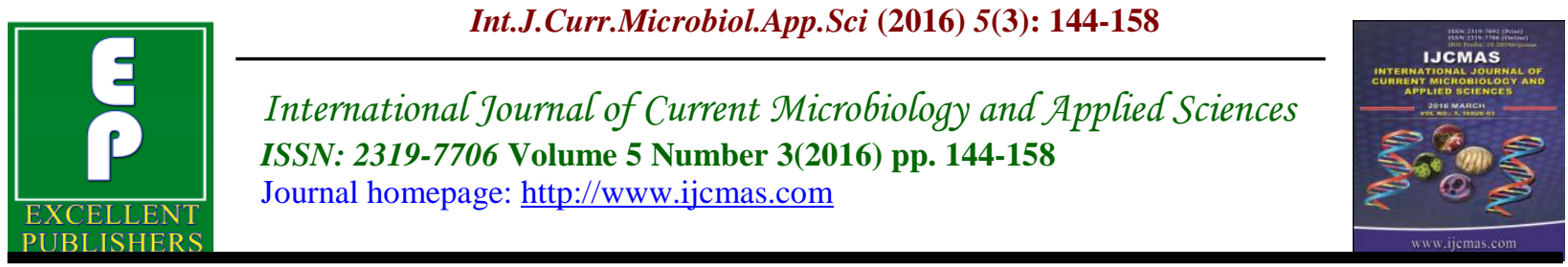

Original Research Article

http://dx.doi.org/10.20546/ijcmas.2016.503.020

\title{
Application of Specific Chromogenic Media and Api Technique for Rapid Confirmation of Listeria monocytogenes in Bulk Tank Milk and Dairy Farms Environment
}

\author{
S.M. Dabash ${ }^{2 *}$, A.M. Saudi ${ }^{1}$, H. El Essawy ${ }^{1}$ and R.H. Hamouda ${ }^{2}$ \\ ${ }^{1}$ Food Hygiene \& Control Department, Faculty of Veterinary Medicine, \\ Cairo University, Giza, Egypt \\ ${ }^{2}$ Researcher Mastitis \& Neonatal Diseases Res. Department Animal Reproduction \\ Research Institute (Al-Haram, Giza, Egypt) \\ *Corresponding author
}

\begin{abstract}
A B S T R A C T
Keywords

Bulk tank milk,

Listeria

monocytogenes,

Chromogenic

media - API

Technique

Article Info

Accepted:

15 February 2016

Available Online:

10, March 2016

The objectives of this study were to identify the prevalence and the sources of contamination of Listeria monocytogenes in BTM of examined 5 farms and to assess the used of the chromogenic media and API technique as rapid confirmation for the presence of this pathogen. The present study was carried on BTM and farm environmental samples collected from 5 dairy farms in Egypt. The samples were examined for the incidence of Listeria species using conventional isolation method and the identification of L. monocytogenes by the using of chromogenic media, API test and PCR technique. The detection method based on PCR amplification of the hlyA gene revealed that the incidence of Listeria monocytogenes were $6.66 \%, 14 \%$, $10 \%, 8 \%, 5.6 \%, 0 \%$ and $0 \%$ in BTM, feces, bedding, water troughs, teat skin, milking equipment and hand swabs, respectively. L. monocytogenes was isolated from 3 out of 5 farms investigated. Antimicrobial susceptibility was done for all identified strains isolated from BTM against 17 antimicrobial agents. All of the isolates were sensitive to Imipenem(IPM), Penicillin G(P), Ampicillin(AMP), Amoxycillin/clavulanic acid(AMC), Ampicillin/ sulbactam (SAM), Chloramphenicol(C), Levofloxacin(LEV), Cephradine, Ciprofloxacin (CIP), Cefquinome(CEQ), Ofloxacin(OFX) and Amikacin(AK).
\end{abstract}

\section{Introduction}

Food safety is a complex issue that has an impact on all segments of the society.

Diseases caused by foodborne pathogens constitute a worldwide public health problem. Listeriosis; a foodborne disease, has been considered to be an emerging zoonotic disease worldwide.
Listeria sp. is one of the most important zoonotic diseases which cause dangerous illness. It consists of six species (Listeria monocytogenes, L. innocua, L. seeligeri, L. welshimeri, L. ivanovii and L. grayi), but the most important one is Listeria monocytogenes. L. monocytogenes is a major concern for the food industry, as it 
can cause Listeriosis in humans (Kathariou, 2002). Listeriosis is one of the most important infections in Europe (European Food Safety Authority-European Centre for Disease Prevention and Control, 2007) and in the United States, the Centers for Disease Control and Prevention estimated that approximately 1,600 persons become seriously ill with listeriosis each year, of whom 16\% die (CDC, 2011).

Exposure to food borne L. monocytogenes may cause fever, muscle aches and gastroenteritis (Riedo et al., 1994). In pregnant women, it may cause abortion (Linnan et al., 1988 and Riedo et al., 1994) or neonatal death (Linnan et al., 1988), although there are rates of illnesses caused by $L$. seeligeri, L. ivanovii and L. innocua (Jeyaletchumi et al., 2010).

Various species of Listeria are commonly found in soil, decaying vegetation, and water, and well as being part of the fecal flora of animals and humans. In dairy cattle, L. monocytogenes can result in several clinical presentations, including encephalitis, septicemia, abortion and mastitis (Radostitis et al., 2007).

Mastitis caused by Listeria is infrequent, but infected mammary glands can shed this pathogen for periods as long as 12 months (Winter et al., 2004). L. monocytogenes is present the dairy farm environment and can survive in the gastrointestinal tract of cows, thus constituting a source of contamination of bulk tank milk (BTM) (Latorre et al., 2009). Listeria monocytogenes is capable of multiplying at temperatures $\leq 7^{\circ} \mathrm{C}$ and surviving in environments with a wide range of $\mathrm{pH}$ values (4.3 to 10) and high salt concentrations (Ryser, 2001).

The prevalence of L. monocytogenes in bulk tank milk has been reported to range from $0.2 \%$ to $20 \%$ (Table 1 ). Another important characteristic that makes $L$. monocytogenes an emerging concern to public health authorities is its ability to form biofilms and survive on materials commonly used in food processing equipment (Wong, 1998). Colonization of dairy processing equipment can result in cross-contamination of pasteurized milk in processing plants, which has been reported to be an important source of human Listeriosis. Introduction of Listeria monocytogenes into food processing plants results in reservoirs that are difficult to eradicate (Wong, 1998).

Sporadic outbreaks of Listeriosis linked to consumption of unpasteurized or crosscontaminated dairy products have occurred (Center for Science in the Public Interest, 2008). The high fatality rate, occurrence of outbreaks, and ability of L. monocytogenes to contaminate both unpasteurized and pasteurized foods has led the Microbiological specifications for food items including milk and dairy products often stipulate absence of L. monocytogenes in $25 \mathrm{~g}$ of food samples (Roberts, et al., 1995) and FDA to adopt a "zero tolerance" policy for the presence of L. monocytogenes in ready-to-eat foods (FDA, 2003). In order to comply with this regulatory policy and minimize the risk of human listeriosis a reduction in the initial contamination of farm BTM has been an important objective of governmental agencies (Hassan, et al., 2000).

Also, due to the increased multidrug resistance in the foodborne pathogen due to increase the use of antimicrobials in feeds for the control and treatment of diseases in animals, this work was carried out to study the prevalence and the antimicrobial susceptibility of L. monocytogenes isolated from milk and dairy farms environment.

Moreover, a rapid and simple diagnostic test that would reduce both the cost and time for identification of contaminated milk would 
be useful for identification of this zoonotic pathogen on dairy farms. Current tests based on traditional microbiology or molecular methods are still expensive and time consuming, which may preclude their use in such programs.

\section{Materials and Methods}

\section{Collection of Samples}

BTM and environmental samples were collected from 5 dairy farms in Kafr-El sheikh Governorate and Alexandria road, Egypt, in between June, 2014 and June 2015. During each farm visit, a variety of environmental and BTM samples were collected (Table 2). Collected samples were transformed to the laboratory in an ice box as soon as possible for bacteriological examination.

\section{Preparation of Samples}

Environmental and BTM milk samples were processed as described by (Latorre et al., 2009). Silage, bedding and fecal samples (50 grams) were mixed with $200 \mathrm{ml}$ of peptone water in two-chamber filter bags.

Samples were stomached for one minute, after which five $\mathrm{ml}$ of the filtered sample were reserved for further incubation in Modified Listeria Enrichment Broth (Difco; BD Diagnostics, Sparks, MD).

Milking equipment swabs for each sampling location were composited in the laboratory by adding $4 \mathrm{ml}$ of Neutralizing Buffer included in each tube to a sterile plastic vial. $5 \mathrm{ml}$ of BTM, water, milking equipment swabs, and all other filtered samples were mixed with $5 \mathrm{ml}$ of concentrated (two times the concentration recommended by the manufacturer) Modified Listeria Enrichment Broth and incubated at $30^{\circ} \mathrm{C}$ for 3 to 5 days.
Isolation of $L$. monocytogenes was done on the Basis Described by ISO 11290-1:1996 + A1:2004BS 5763-18:1997

Briefly, ten $\mathrm{ml}$ of the milk samples were added to $90 \mathrm{ml}$ of Listeria primary enrichment of Half Fraser Broth (Oxoid, CM0895 + SR0166). Incubate for $24 \mathrm{hr} \pm 2$ $\mathrm{hr}$ at $30^{\circ} \mathrm{C}$ then transfer $0.1 \mathrm{ml}$ of primary enrichment culture to $10 \mathrm{ml}$ of Fraser Broth (Oxoid, CM0895 + SR0156) and incubate for $48 \mathrm{hr} \pm 2 \mathrm{hr}$ at $37^{\circ} \mathrm{C}$.

A loopful of secondary enrichment broth was then streaked onto the surface of Palcam medium (Oxoid, CM0877+ SR0150) and Oxford medium (CM0856 + SR0140) and incubate for $24 \mathrm{hr} \pm 3 \mathrm{hr}$ at $37^{\circ} \mathrm{C}$.

Colonies of presumptive Listeria spp from each selective agar plate were streaked on Tryptone Soya Yeast Extract Agar (TSYEA - Oxoid, CM0862 + 9-18g Agar) and Incubate for $24 \mathrm{hr}$ at $37^{\circ} \mathrm{C}$ for purification.

\section{Morphological and Biochemical Identification}

All Purified presumptive Listeria isolates were examined for Gram's reaction, Motility, Blood haemolysis test (Blood agar base-Oxoid, CM854), CAMP test (CFSAN, 2001), sugars fermentation tests, Nitrate reduction and Catalase production.

Detection of L. monocytogenes on Chromogenic Media (ALOA) (ISO/ DIS11290-1/2004) Refer to Standards ISO 11290-1 \& -2 Amendment 1(2004)

The positive biochemical samples for Listeria spp. in BTM and environmental samples were exposed to chromogenic media (ALOA) to quantify the result. Typically, this is done by preparing sample 
dilutions in BPW, or enrichment broth without supplements, plating each dilution onto ALOA and incubated at $37^{\circ} \mathrm{C}$ for 24 hours $\pm 3 \mathrm{hr}$. Typical L. monocytogenes were blue to blue-green colonies, round, regular, with opaque halo, diameter from one to 2 mm.

Identification of Listeria spp. using the API Test (Beumer, et al., 1996)

10300 API Listeria (bioMerieux, Marcyl'Etoile, France) consists of the following 10 tests: enzymatic substrate, hydrolysis of Aesculin, acid production from D-arabitol, D-xylose, L-rhamnose, $\alpha$-methyl- Dglucose, $\alpha$-methyl- D-mannose, D-ribose, glucose-1-phosphate and D-tagatose.

Suspected isolated Listeria spp. colonies were picked up and emulsified in an ampoule of API suspension medium $(2 \mathrm{ml})$; turbidity of inoculated medium was adjusted to $1 \mathrm{McF}$ arland. The incubation box was prepared (tray and lid) and about $3 \mathrm{ml}$ of distilled water was distributed into the honeycombed wells of the tray to create a humid atmosphere. The strip was removed from its individual packaging, placed in the incubation box. After inoculation by the suspected colonies the strip box was closed and incubated for $18-24$ hours at $37^{\circ} \mathrm{C}$ in aerobic conditions. Reaction results were determined according to color changes as an indicator as per manufacturer s instructions.

Molecular Detection of L. Monocytogenes using PCR Technique

\section{Extraction of Genomic DNA from Cultures}

Genomic DNA was extracted from the isolates of presumptive L. monocytogenes using QIAamp DNA mini kit instructions (Qiagen Pty Ltd, Australia), according to the manufacturer's protocol. Catalogue no.51304.

\section{DNA Amplification by Polymerase Chain Reaction}

Temperature and time conditions of the two primers during PCR are shown in Table (4) according to specific authors and Emerald Amp GT PCR mastermix (Takara) kit Code No. RR310A

\section{The PCR Product Visualization}

The amplicons of $553 \mathrm{bp}(16 \mathrm{~S}$ Rrna gene) and 174 bp(hlyA gene) of listeria monocytogenes were visualized by running in $2.5 \%$ agarose gel (Agarose gel was mixed in ethidium bromide) running by using horizontal gel electrophoresis, according to (Sambrook et al., 1989) with modification.

The horizontal electrophoresis unit was connected by the power supply, which was $1-5$ volts/cm of the tank length. The run was stopped after about $30 \mathrm{~min}$ and the gel was transferred to UV cabinet. The gel was photographed by a gel documentation system and the data was analyzed through computer software. The positive samples were detected by presence of amplified DNA fragment at expected size.

\section{Antibiotic Sensitivity Test}

Antimicrobial resistance of Listeria monocytogenes strains isolated from BTM were carried out against 17 antimicrobial agents. The standard antibiotic discs obtained from (Oxoid, Basingstoke, UK). The antimicrobial susceptibility testing of the isolates was performed by using the disc diffusion method according to recommendations of the national committee for clinical laboratory standard (NCCLS, 2002). 


\section{Result and Discussion}

A total of 895 samples of which 75 were bulk tank milk of cattle origin, 250 feces samples, 50 samples from bedding material, 50 samples from water troughs, 250 teat skin swabs, 170 milking equipments' swabs (teat cups, pipelines, jars) and 50 hand swabs from dairy workers were collected from 5 dairy farms in Kafr-El-sheikh Governorate and Alexandria road, Egypt. The collected samples were examined for the prevalence of Listeria monocytogenes by conventional method and Presumptive positive Listeria monocytogenes isolates were further identified to species level by chromogenic media, API listeria strips and PCR to evaluate its accuracy.

The results show that the prevalence percentages of Listeria monocytogenes were $20,20,30,14,12,0$ and 0 using conventional method; 9.33, 15.2, 14, 10, 7.2, 0 and 0 using Chromogenic media; 6.66, $14.8,10,8,6.4,0$ and 0 using API tests and $6.66,14,10,8,5.6,0$ and $0 \%$ using PCR technique in BTM, feces, bedding, Water troughs, teat skin swabs, milking equipments' swabs and hand workers swabs respectively (Table 5).

The isolation and identification of $L$. monocytogenes by different identification methods revealed that there was no significant difference in the incidence of $L$. monocytogenes in BTM and environmental farm samples by using API tests and PCR technique, similar results was recorded Srividya, et al., (2013). However both Palcam and Oxford selective agar media could not compared to CHROMagar Listeria because the former two were generally used for detection of Listeria spp. while the latter enables direct detection of $L$. monocytogenes. The use of PALCAM agar and Listeria selective agar did not allow one-step detection of L. monocytogenes as further identification with biochemical test or PCR was needed to differentiate $L$. monocytogenes from other Listeria spp. Our results agree with, Jamali, et al., 2013.

Therefore PCR result was used as final confirmation of the identity of $L$. monocytogenes colonies isolated in this current study.

Nearly Similar incidence of $L$. monocytogenes in BTM was recorded by Van Kessel, et al., (2004), where the incidence of contamination was $6.5 \%$. Abd ElAal \& Atta (2009), Waak, et al., (2002) and Rafie et al., (2013) reported low incidence of $0.2 \%, 1.0 \%$ and $2.02 \%$ respectively, while higher incidence were reported by Amal (2014), Pantoja, et al., (2012) and Hassan, et al., (2000), 20, 16 and 12.6 respectively.

Currently, Listeria monocytogenes is considered one of the most important pathogens responsible for food-borne infection. It is often incriminated in outbreaks of human listeriosis (Ryser and Marth, 2007). Milk and dairy products contaminated with Listeria monocytogenes have been responsible for human listeriosis outbreaks (Dalton et al., 1997). Pregnant women, infants, immune-compromised and the elderly people are at greatest risk for listeriosis (Gillespie et al., 2010).

The serious consequences of listeriosis, such as a septicemia in elderly and immune compromised people, and abortion in pregnant women or death of their newborn constitute a serious threat to public health.

Another complication is that Listeria is able to grow well at law temperatures. Thus, refrigeration is not as effective in preventing growth of Listeria in food as it is for most 
other bacteria that cause food-borne disease (Salyers and Whitt 2002).

Examination of farm environment samples show that the incidence of L. monocytogenes was highest in fecal samples, $14 \%$, nearly Similar finding were reported by Husu, 1990 and Fedio et al., 1992 16.1\% and 14.5\% respectively, lower incidence was reported by Hakan, 2003 was $1.53 \%$. While our result was lowest in teat swabs, 5.6\%, higher incidence were reported by Mohammed et al., 2009 was $19 \%$.

The incidence of $L$. monocytogenes in bedding samples were 10\%, higher incidence were reported by ueno et al., 1996 and mohammed et al., 2009 were $22 \%$ and $30 \%$ respectively; while our incidence in water samples were $8 \%$, lower incidence were reported by Pantoja et al., (2012) and Atil et al., (2011) were $6 \%$ and $4.5 \%$ respectively.

On the other hand L. monocytogenes failed to be isolated from milking equipments and hand swabs samples, similar results to our study were reported by pantoja et al., 2012 and Atil et al., 2011.

Raw milk was identified as a source of $L$. monocytogenes, common sources of $L$. monocytogenes in raw milk have been reported to be fecal (Husu, 2010) but environmental contaminations during milking have also been reported (Frece et al., 2010). Listeria monocytogenes was isolated from BTM and different environmental samples obtained from 3 out of 5 farms examined. In farm A and B $L$. monocytogenes were isolated from BTM, feces, bedding, water troughs and teat skin swabs in percentages of $20,34,20,20 \& 18$ and 13.33, 24, 20, $20 \& 10$ respectively, while on farm $\mathrm{C}$, Listeria monocytogenes was only isolated from feces and bedding materials in percentages of 12 and 10 , respectively (Table 6). High isolation rates of the organism in farm A and B may have been caused by shedding of the organism in the Feces of the cow from which farm environment were contaminated.

L. monocytogenes was isolated from feces and bedding material of farm $E$ in percentages of 12 and 10 respectively, while farm $\mathrm{C}$ and $\mathrm{D}$ were free completely from $L$. monocytogenes (Table 6).

A similarity was seen in the distribution of the organisms at the two farms, A and B where the milking were manual and the hygienic conditions at the two dairy farms were poor. Further, it was observed that most of the milking animals are not regularly screened for diseases and as a result, there is a great danger of some diseases being transmitted to human beings.

The farm $\mathrm{C}, \mathrm{D}$ and $\mathrm{E}$ were using milking machine. Despite the high cost of milking machine, it is highly effective and helpful to produce clean milk without any direct contact with the farmers and the surroundings. On the contrary Latorre et al., 2009 concluded that the milking machine was the most likely source of contamination.

Regardless of the source of contamination, it is important to note that results of this and previous studies (Latorre, et al., 2009 and Pantoja, et al., 2012) demonstrate that farms can develop persistent sources of BTM contamination with L. monocytogenes. Therefore, longitudinal screening of BTM and dairy environment could be valuable for programs developed to improve the safety of milk. Identification of such contaminated farms could not only minimize the risk of listeriosis for consumers of unpasteurized dairy products but also prevent colonization of milk processing facilities and further cross contamination of pasteurized dairy products (Pantoja, et al., 2012). 
Table.1 Surveys on the Isolation of L. monocytogenes from BTM

\begin{tabular}{|c|l|}
\hline \multicolumn{2}{|c|}{$\begin{array}{c}\text { Table.1Surveys on the isolation of } \\
\text { L. monocytogenes from BTM }\end{array}$} \\
\hline $\begin{array}{c}\text { Isolation } \\
\text { rate (\%) }\end{array}$ & \multicolumn{1}{|c|}{ Reference } \\
\hline 5.08 & O'Donnell, (1995) \\
2.7 & Steele, et al., (1997) \\
12.6 & Hassan, et al., (2000) \\
4.6 & Jayarao \& Henning (2001) \\
1.0 & Waak, et al., (2002) \\
4.9 to 7.0 & Muraoka, et al. (2003) \\
6.5 & Van Kessel, et al., (2004) \\
0.2 & Abd ElAal \& Atta (2009) \\
$9.8 \%$ & Ljupco, et al., (2012) \\
16 & Pantoja, et al., (2012) \\
2.02 & Rafie et al., (2013) \\
8 & AL-Ashmawy, et al., \\
$10,20 \& 10$ & (2014) \\
\hline
\end{tabular}

Table.2 The Collected Samples from the Dairy Farms

\begin{tabular}{|c|c|c|c|}
\hline \multicolumn{4}{|c|}{ Table (2): The collected samples from the dairy farms. } \\
\hline Source & Size & References & $\begin{array}{c}\text { No. of } \\
\text { samples }\end{array}$ \\
\hline BTM & $\begin{array}{l}60-\mathrm{ml} / \text { sterile } \\
\text { bottle }\end{array}$ & ISO 707: 2008 & 75 \\
\hline Feces & $\begin{array}{l}\text { Full 1-L plastic } \\
\text { bag }\end{array}$ & OIE, 2013 & 250 \\
\hline Bedding & $\begin{array}{l}\text { Full 1-L plastic } \\
\text { bag }\end{array}$ & $\begin{array}{l}\text { Clegg et al, } \\
1983\end{array}$ & 50 \\
\hline $\begin{array}{l}\text { Water } \\
\text { troughs }\end{array}$ & $\begin{array}{l}200 \mathrm{ml} \text { in sterile } \\
\text { cup }\end{array}$ & APHA, 1995 & 50 \\
\hline $\begin{array}{l}\text { Teat skin \& } \\
\text { orifice } \\
\text { swabs }\end{array}$ & $\begin{array}{l}4 \text { ml BPW } \\
\text { (Oxoid, CM1049) } \\
\text { /swab }\end{array}$ & $\begin{array}{l}\text { Rendos et al., } \\
1975\end{array}$ & 250 \\
\hline $\begin{array}{l}\text { Dairy } \\
\text { equipments } \\
\text { and utensils }\end{array}$ & $\begin{array}{l}4 \mathrm{ml} \text { sterile } 1 / 4 \\
\text { strength ringer's } \\
\text { solution Oxoid: } \\
\text { BR005/swab }\end{array}$ & $\begin{array}{l}\text { ISO/FDIS } \\
\text { 18593:2004 }\end{array}$ & 170 \\
\hline $\begin{array}{l}\text { worker } \\
\text { hands }\end{array}$ & $4 \mathrm{ml} \mathrm{BPW} / \mathrm{swab}$. & $\begin{array}{l}\text { ISO/FDIS } \\
\text { 18593:2004 }\end{array}$ & 50 \\
\hline
\end{tabular}


Table.3 List of Primers Used in the Identification of Listeria monocytogenes

\begin{tabular}{|c|c|c|c|}
\hline Primer & Sequence & $\begin{array}{c}\text { Amplified } \\
\text { product }\end{array}$ & Reference \\
\hline $16 S$ rRNA & $\begin{array}{c}\text { CCT TTG ACC ACT CTG GAG ACA GAG C } \\
\text { AAG GAG GTG ATC CAA CCG CAC CTT C }\end{array}$ & $553 \mathrm{bp}$ & Lantz et al., 1994 \\
\hline hlyA & $\begin{array}{l}\text { GCA-TCT-GCA-TTC-AAT-AAA-GA } \\
\text { TGT-CAC-TGC-ATC-TCC-GTG-GT }\end{array}$ & $174 \mathrm{bp}$ & $\begin{array}{c}\text { Deneer and } \\
\text { Boychuk, 1991 }\end{array}$ \\
\hline
\end{tabular}

Table.4 Cycling Conditions of the Different Primers During Cpcr

\begin{tabular}{|c|c|c|c|c|c|c|}
\hline Gene & $\begin{array}{c}\text { Primary } \\
\text { denaturation }\end{array}$ & $\begin{array}{c}\text { Secondary } \\
\text { denaturation }\end{array}$ & Annealing & Extension & $\begin{array}{l}\text { No. of } \\
\text { cycles }\end{array}$ & $\begin{array}{c}\text { Final } \\
\text { extension }\end{array}$ \\
\hline $\begin{array}{c}16 S \\
\text { Rrna }\end{array}$ & $\begin{array}{c}94^{\circ} \mathrm{C} \\
5 \mathrm{~min} .\end{array}$ & $\begin{array}{c}94^{\circ} \mathrm{C} \\
30 \mathrm{sec}\end{array}$ & $\begin{array}{c}60^{\circ} \mathrm{C} \\
45 \mathrm{sec}\end{array}$ & $\begin{array}{l}72^{\circ} \mathrm{C} \\
45 \mathrm{sec}\end{array}$ & 35 & $\begin{array}{c}72^{\circ} \mathrm{C} \\
10 \mathrm{~min} .\end{array}$ \\
\hline hlyA & $\begin{array}{l}94^{\circ} \mathrm{C} \\
5 \mathrm{~min} .\end{array}$ & $\begin{array}{c}94^{\circ} \mathrm{C} \\
30 \mathrm{sec} .\end{array}$ & $\begin{array}{c}50^{\circ} \mathrm{C} \\
30 \mathrm{sec} .\end{array}$ & $\begin{array}{l}72^{\circ} \mathrm{C} \\
30 \mathrm{sec} .\end{array}$ & 35 & $\begin{array}{l}72^{\circ} \mathrm{C} \\
7 \mathrm{~min} .\end{array}$ \\
\hline
\end{tabular}

Table.5 Incidence of L. monocytogenes in Btm and Environmental Farm Samples using Different Identification Methods

\begin{tabular}{|c|c|c|c|c|c|c|c|c|c|}
\hline \multirow{3}{*}{ Sample type } & \multirow{3}{*}{$\begin{array}{c}\text { Sample } \\
\text { numbers }\end{array}$} & \multicolumn{8}{|c|}{ Positive samples for Listeria monocytogenes } \\
\hline & & \multicolumn{2}{|c|}{$\begin{array}{c}\text { Conventional } \\
\text { Method }\end{array}$} & \multicolumn{2}{|c|}{$\begin{array}{c}\text { Chromogenic } \\
\text { media }\end{array}$} & \multicolumn{2}{|c|}{$\begin{array}{c}\text { API } \\
\text { Tests }\end{array}$} & \multicolumn{2}{|c|}{$\begin{array}{c}\text { PCR } \\
\text { Technique }\end{array}$} \\
\hline & & NO. & $\%$ & NO. & $\%$ & NO. & $\%$ & NO. & $\%$ \\
\hline BTM & 75 & 15 & 20 & 7 & 9.33 & 5 & 6.66 & 5 & 6.67 \\
\hline Feces & 250 & 50 & 20 & 38 & 15.2 & 37 & 14.8 & 35 & 14 \\
\hline Bedding & 50 & 15 & 30 & 7 & 14 & 5 & 10 & 5 & 10 \\
\hline Water troughs & 50 & 7 & 14 & 5 & 10 & 4 & 8 & 4 & 8 \\
\hline - $\quad$ Teat swabs & 250 & 30 & 12 & 18 & 7.2 & 16 & 6.4 & 14 & 5.6 \\
\hline *Milking equipments & 170 & 0 & 0 & 0 & 0 & 0 & 0 & 0 & 0 \\
\hline Hand swabs & 50 & 0 & 0 & 0 & 0 & 0 & 0 & 0 & 0 \\
\hline
\end{tabular}

Table.6 The Incidence of Listeria monocytogenes in Different Farms Examined

\begin{tabular}{|c|c|c|c|c|c|c|c|c|c|c|c|c|c|c|}
\hline \multirow[t]{3}{*}{ Farms } & \multicolumn{2}{|c|}{$\begin{array}{c}\text { BTM } \\
(15)\end{array}$} & \multicolumn{2}{|c|}{$\begin{array}{c}\text { Feces } \\
(50)\end{array}$} & \multicolumn{2}{|c|}{$\begin{array}{l}\text { Bedding } \\
\quad(10)\end{array}$} & \multicolumn{2}{|c|}{$\begin{array}{l}\text { Water } \\
(10)\end{array}$} & \multicolumn{2}{|c|}{$\begin{array}{c}\text { Teat } \\
\text { swab } \\
(50) \\
\end{array}$} & \multicolumn{2}{|c|}{$\begin{array}{c}\text { Milking } \\
\text { equipments } \\
(10)\end{array}$} & \multicolumn{2}{|c|}{$\begin{array}{c}\text { Hands } \\
\text { swabs } \\
(10) \\
\end{array}$} \\
\hline & \multicolumn{14}{|c|}{ Positive samples } \\
\hline & No & $\%$ & No & $\%$ & No & $\%$ & No & $\%$ & No & $\%$ & No & $\%$ & No & $\%$ \\
\hline Farm A Manual & 3 & 20 & 17 & 34 & 2 & 20 & 2 & 20 & 9 & 18 & 0 & 0 & 0 & 0 \\
\hline Farm B Manual & 2 & 13.33 & 12 & 24 & 2 & 20 & 2 & 20 & 5 & 10 & 0 & 0 & 0 & 0 \\
\hline Farm C & 0 & 0 & 0 & 0 & 0 & 0 & 0 & 0 & 0 & 0 & 0 & 0 & 0 & 0 \\
\hline Farm D & 0 & 0 & 0 & 0 & 0 & 0 & 0 & 0 & 0 & 0 & 0 & 0 & 0 & 0 \\
\hline Farm E & 0 & 0 & 6 & 12 & 1 & 10 & 0 & 0 & 0 & 0 & 0 & 0 & 0 & 0 \\
\hline
\end{tabular}

The numbers in parentheses represent the numbers of samples taken from each farm 
Table.7 Antimicrobial Susceptibility Profiles of L. monocytogenes isolated from btM

\begin{tabular}{|l|c|c|c|c|c|c|}
\hline \multirow{2}{*}{ Antimicrobial agent } & Disk & \multirow{2}{*}{$\begin{array}{c}\text { Code } \\
\text { content }\end{array}$} & $\begin{array}{c}\text { (Oxoid } \\
\text { level }(\mu \mathrm{g})\end{array}$ & Resistance & \multicolumn{2}{|c|}{ Sensitivity } \\
\cline { 5 - 8 } & $10 \mu \mathrm{g}$ & CT0455B & 0 & 0 & 5 & 100 \\
\hline Imipenem(IPM) & $10 \mathrm{Unit}$ & CT0043B & 0 & 0 & 5 & 100 \\
\hline Penicillin G(P) & $10 \mu \mathrm{g}$ & CT0003B & 0 & 0 & 5 & 100 \\
\hline Ampicillin(AMP) & $30 \mu \mathrm{g}$ & CT0223B & 0 & 0 & 5 & 100 \\
\hline Amoxycillin/ clavulanic acid(AMC) & $30 \mu \mathrm{g}$ & CT1653B & 0 & 0 & 5 & 100 \\
\hline Ampicillin/sulbactam(SAM) & $30 \mu \mathrm{g}$ & CT0013B & 0 & 0 & 5 & 100 \\
\hline Chloramphenicol(C) & $5 \mu \mathrm{g}$ & CT1587B & 0 & 0 & 5 & 100 \\
\hline Levofloxacin(LEV) & $30 \mu \mathrm{g}$ & CT0063B & 0 & 0 & 5 & 100 \\
\hline Cephradine & $5 \mu \mathrm{g}$ & CT0425B & 0 & 0 & 5 & 100 \\
\hline Ciprofloxacin(CIP) & $30 \mu \mathrm{g}$ & ---- & 0 & 0 & 5 & 100 \\
\hline Cefquinome(CEQ) & $5 \mu \mathrm{g}$ & CT0446B & 0 & 0 & 5 & 100 \\
\hline Ofloxacin(OFX) & $30 \mu \mathrm{g}$ & CT0107B & 0 & 0 & 5 & 100 \\
\hline Amikacin(AK) & 10 & CT0024B & 1 & 20 & 4 & 80 \\
\hline Gentamicin(CN) & 15 & CT0020B & 1 & 20 & 4 & 80 \\
\hline Erythromycin(E) & 10 & CT0032B & 2 & 40 & 3 & 60 \\
\hline Neomycin & 30 & CT0054B & 2 & 40 & 3 & 60 \\
\hline Tetracycline(TE) & 10 & CT0047B & 3 & 60 & 2 & 40 \\
\hline Streptomycin(S) & & & &
\end{tabular}

Fig.1: API-10300 Listeria showing positive results for identification of Listeria monocytogenes

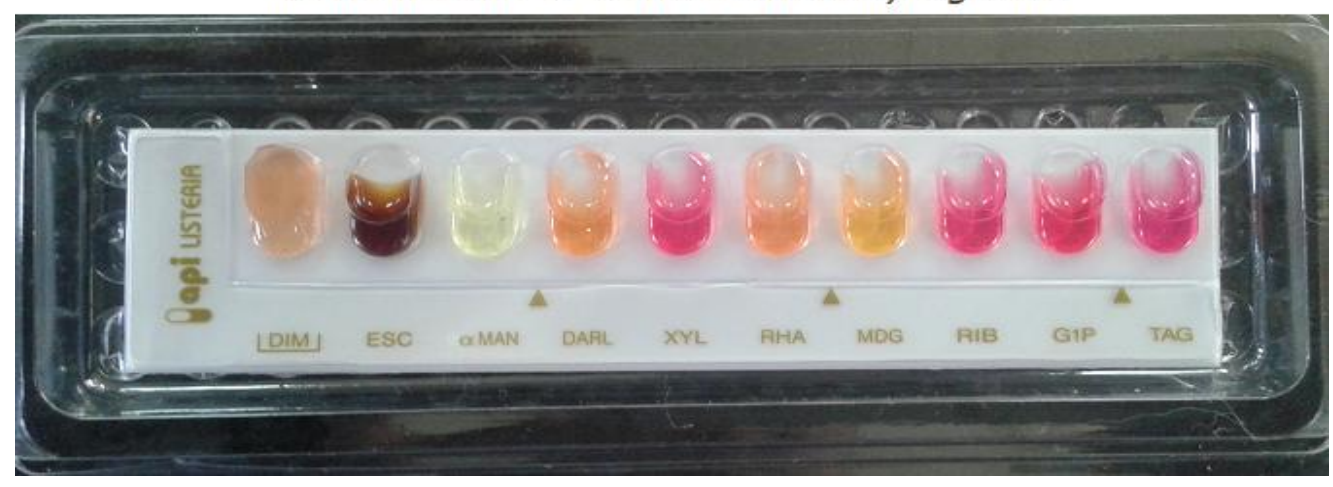




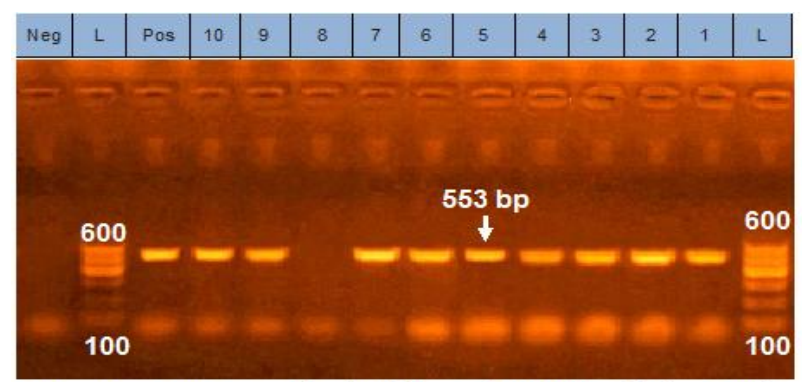

Fig. (2): Agarose gel showing polymerase chain reaction amplified product of $553 \mathrm{bp}$ for $16 S \mathrm{rRNA}$ gene in $L$. monocytogenes isolates, Lane $1,2,3,4,5,6,7,9$ and 10:Samples positive for $16 S r R N A$ gene, Lane 8: sample negative for Samples positive for $16 S$ rRNA gene, Lane (pos): Positive control, Lane neg: Negative control, Lane L: $100 \mathrm{pb}$ DNA ladder (DNA marker).

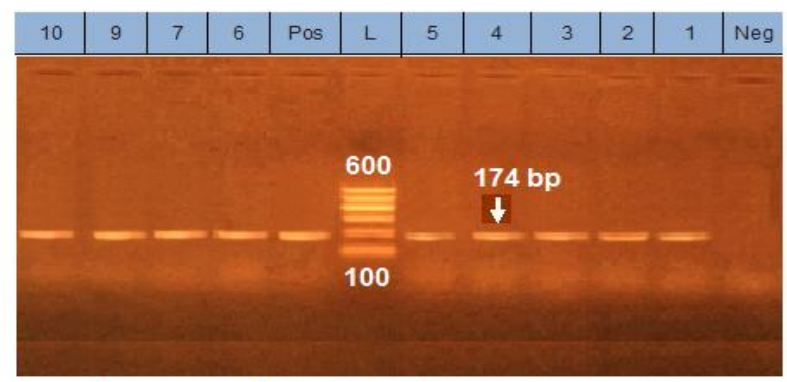

Fig. (3): Agarose gel showing PCR amplified product of 174 $\mathrm{bp}$ for hlyA gene in L. monocytogenes isolates, Lane 1, 2, 3, 4, 5, 6, 7, 9 and 10: Samples positive for $h l y A$, Lane (pos): Positive control, Lane neg: Negative control, Lane L: 100pb DNA ladder (DNA marker)

\section{Fig.4 Incidence of L. monocytogenes in BTM and Environmental Farm Samples}

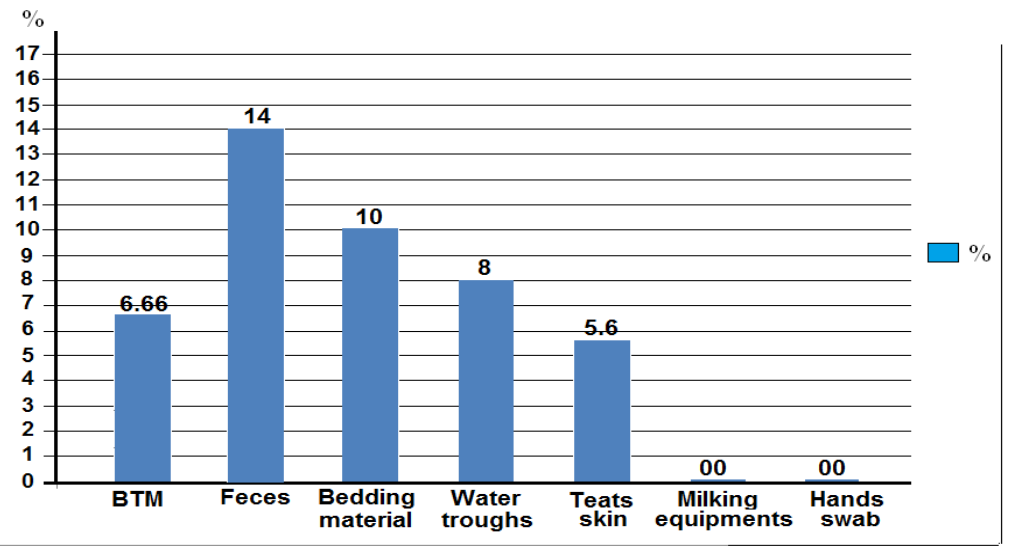

The safety of milk is an important attribute of consumers of milk and dairy products. Milk pasteurization safeguards consumers from many potential food borne hazards. Despite the pasteurization process, the quality and safety of raw milk are important in reducing the risk of food borne diseases associated with milk because raw milk is the starting point of the milk productionconsumption chain.

Antimicrobial resistance of Listeria monocytogenes strains $(n=5)$ isolated from 5 BTM samples of farm A and B against 17 antimicrobial agents were evaluated, the results show that all of the isolates $(100 \%)$ were sensitive to Imipenem(IPM), Penicillin G(P), Ampicillin(AMP), Amoxycillin/ clavulanic acid(AMC), Ampicillin/ sulbactam(SAM), Chloramphenicol (C), Levofloxacin(LEV), Cephradine, Ciprofloxacin(CIP), Cefquinome (CEQ), Ofloxacin (OFX) and Amikacin (AK). Four strains $(80 \%)$ were sensitive to Gentamicin and Erythromycin, 3 strains (60\%) were sensitive to Neomycin and Tetracycline, while two strains $(40 \%)$ were sensitive to Streptomycin (Table 7).

Several studies have described differences in susceptibility of isolates obtained from farms with different histories of potential exposure to antimicrobials (Tikofsky et al., 2003; Sato et al., 2004; Rajala-Schultz et al., 2004; Berghash et al., 1983). 
Nearly similar results were recorded by Farouk, et al., (2015), who found that all isolates $(100 \%)$ were sensitive to penicillin $\mathrm{G}$, ampicillin, tetracyclin, amikacin and erythromycin. Also our results was nearly similar to Rota, et al., (1996) and Slade and Collins-Thompson, (1990) they reported that Listeria is usually susceptible to a wide range of antibiotics especially ampicillin and ampicillin \& erythromycin, respectively.

Bulk tank milk might be a potential source of L. monocytogenes which poses a significant clinical threat to consumers through excessive use of various antibiotics against this organism.

In conclusion, results of this study strongly suggest that the contamination of BTM with $L$. monocytogenes originated from inefficient cleaned and sanitized of dairy cows udder and stored water used for washing of equipment and drinking of animals. The results indicate that farm's environment can develop persistent sources of contamination.

Milk pasteurization safeguards consumers from many potential food borne hazards in milk and milk products. Despite the pasteurization process, the quality and safety of raw milk are important in reducing the risk of food borne diseases associated with milk because raw milk is the starting point of the milk production-consumption chain.

Results of this study demonstrated that $L$. monocytogenes isolated from the BTM of two dairy farms were susceptible to a wide range of antibiotics.

\section{References}

Abd Elaal, S.F.A., Atta, M.A-H.B. 2009. Occurrence of Listeria and Yersinia species in milk and some milk products. Assiut Vet. Med. J., (Recevied at 20/8/2009). Vol.55, No. 123.

AL-Ashmawy Maha, A.M., Gwida, Mayada, M., Abdelgalil, Khaled, H. 2014. Prevalence, Detection Methods and Antimicrobial Susceptibility of L. monocytogens isolated from milk and soft cheeses and its zoonotic importance: World App. Sci. J., 29(7): 869-878.

Amal, M. Eid. 2014. Molecular identification of some contagious microorganisms causing food poisoning from bulk tank milk in Gharbia Governorate. Benha Vet. Med. J., Vol.27, No.2: 29-47.

Atil, E., Ertas, H.B., Ozbey, G. 2011. Isolation and molecular characterization of Listeria spp. from animals, food and environmental samples. Vet. Medi., 56(8): 386-394.

Berghash, S.R., Davidson, J.N., Armstrong, J.C., Dunny, G.M. 1983. Effects of antibiotic treatment of nonlactating dairy cows on antibiotic resistance patterns of bovine mastitis pathogens. Antimicrobial Agents And Chemotherapy, 771-776.

Beumer, R.R., Giffel, M.C., Kok, M.T.C., Rombouts, F.M. 1996. Confirmation and identification of Listeria spp. Lett. App. Microbiol., 22: 448-452.

CDC (Centers for Disease Control and Prevention). 2011. Listeriosis: Technical information. Available at: http://www.cdc.gov/nczved/divisions dfbmd/diseases/listeriosis/ technical.html. Accessed May 15

Center for Science in the Public Interest. 2008. Outbreak alert: closing the gaps in our federal food safety net. Available

at: www.cspinet.org/new/pdf/outbreak_ alert_2008_report_final.pdf. Accessed March 10, 2010. 
CFSAN (Center of Food safety and Applied Nutrition) 2001. Bacteriological analytical Manual online, Listeria monocytogenes. U.S. Food \& drug Admin., Chapter 10, pp: 198-212.

Clegg, F.G., chiejina, S.N., Duncan, A.L., Kay, R.N., Wary, C. 1983. Outbreak of salmonella Newport infection in dairy herds and their relationship to management and contamination of environment. Vet. Res.,112(25): 580584.

Dalton, C.B., Austin, C.C., Sobel, J., Hayes, P.S., Bibb, W.F., Graves, L.M., Swaminathan, B., Proctor, M.E., Griffin, P.M. 1997. An outbreak of gastroenteritis and fever due to Listeria monocytogenes in milk. New Eng. J. Med., 336: 100-105.

Deneer, H.G., Boychuk, I. 1991. SpeciesSpecific Detection of Listeria monocytogenes by DNA Amplification. App. Environ. Microbiol., pp. 606-609.

European Food Safety Authority-European Centre for Disease Prevention and Control. 2007. The Community summary report on trends and sources of zoonoses, zoonotic agents, antimicrobial resistance and foodborne outbreaks in the European Union in 2006.

Farouk, M., Abdel-shafi, S., Shalaby, M., Mohamed, R. 2015. Application of specific media, API technique and pcr for rapid confirmation of Listeria monocytogenes in foodstuffs and water. Res. J. Microbiol., 10(3): 100 113.

FDA (Food and Drug Administration). 2003. Listeria monocytogenes risk assessment: I. Introduction. Available at:

Fedio, W.M., Jackson, H. 1992. On the origin of Listeria monocytogenes in raw bulk-tank milk. Int. Dairy J., 2:
197-208.

Frece, J., Markov, K., Cvek, D., Kolarec, K., Delas, F. 2010. Comparison of conventional and molecular methods for the routine confirmation of Listeria monocytogenes in milk products produced domestically in Croatia. $J$. Dairy Res., 77: 112-116.

Gillespie, I.A., Mook, P., Little, C.L., Grant, K.A., Mclauchlin, J. 2010. Human Listeriosis in England, 2001-2007: association with neighborhood deprivation. Euro surveillance, 15(27): pp. 19609.

Hakan, K. 2003. Detection of Listeria monocytogenes in Faeces from Chickens, Sheep and Cattle in Elaz Province. Turk. J. Vet. Anim. Sci., 27: 449-451.

Hassan, L., Mohammad, H.O., McDonough, P.L., Gonzalez, R.N. 2000. A crosssectional study on the prevalence of Listeria monocytogenes and Salmonella in New York dairy herds. J. Dairy Sci., 83: 2441-2447.

http://www.fda.gov/Food/ScienceResearch/ ResearchAreas/RiskAssessmentSafety Assessment/ucm184052.htm. Accessed May 5, 2011.

Husu, J.R. 2010. Epidemiological Studies on the Occurrence of Listeria monocytogenes in the Feces of Dairy Cattle. J. Vet. Med., Series B. 37: 276282.

Husu, J.R. 1990. Epidemiological studies on the occurrence of Listeria monocytogenes in the feces of dairy cattle. J. Vet. Med., B. 37: 276-282.

ISO 11290-1:1996+A1:2004BS 576318:1997 (International Standard Organization). Microbiology of food and animal feeding stuffs. Horizontal method for the detection and enumeration of Listeria monocytogenes. - Part 1: Detection method. International Standard ISO 
11290-1. International Organization for Standardization. Geneva, Switzerland.

ISO EN 707:2008. (International Standard Organization). Milk and milk products - Guidance on sampling.

ISO/FDIS 18593:2004. (International Standard Organization): Microbiology of food and animal feeding stuffHorizontal methods for sampling techniques from surfaces using contact plates and swabs.

Jamali, H., Chai, C.L., Thong, K.L. 2013. Detection and isolation of Listeria spp. and Listeria monocytogenes in readyto-eat foods with various selective culture media; Food Control., 32: 1924.

Jayarao, B.M., Henning. D.R. 2001. Prevalence of foodborne pathogens in bulk tank milk. J. Dairy Sci., 84: $2157-$ 2162.

Jeyaletchumi, P., Tunung, R., Margaret, S.P., Son, R., Farinazleen, M.G. 2010. Detection of Listeria monocytogenes in foods. Int. Food Res. J., 17: 1-11.

Kathariou, S. 2002. Listeria monocytogenes virulence and pathogenicity, a food safety perspective. J. Food Prot., 65: 1811-1829.

Lantz, P.G., Hahn-Hägerdal, B., Rådström, P. 1994. Sample preparation methods in PCR-based detection of food pathogens. Trends Food Sci. Technol., 5: 384-389.

Latorre, A.A., Kessel, J.A., Karns, J.S., Zurakowski, M.J., Pradhan, A.K., Zadoks, R.N., Boor, K.J., Schukken, Y.H. 2009. Molecular ecology of Listeria monocytogenes: Evidence for a reservoir in milking equipment on a dairy farm. Appl. Environ. Microbiol., 75: 1315-1323.

Linnan, M.J., Mascola, L., Lou, X.D., Goulet, V., May, S., Salminen, C., Hird, D.W., Yonekura, M.L., Hayes,
P., Weaver, R., Audurier, A., Plikaytis, B.D., Fannin, S.L., Kleks, A., Broome, C.V. 1988. Epidemic listeriosis associated with Mexican-style cheese. N. Engl. J. Med., 319: 823-828.

Ljupco, A., Dean, J., Marija, R., Mirko, P., Sandra, M., Pavle, S. 2012. Assessment of the microbial parameters along the production phases at a dairy plant. Mac. Vet. Rev., 35(1): 23-28.

Mohammed, H.O., Stipetic, K., McDonough, P.L., Gonzalez, R.N., Nydam, D.V., Atwill, E.R. 2009. Identification of potential on-farm sources of Listeria monocytogenes in herds of dairy cattle. Am. J. Vet. Res., 70(3):383-8.

doi: 10.2460/ajvr.70.3.383

Muraoka, W., Gay, C., Knowles, D. 2003. Prevalence of $L$. monocytogenes subtypes in bulk tank milk of the Pacific Northwest. J. Food Prot., 66: 1413-1419.

NCCLS (National Committee for Clinical Laboratory Standards) (2002). Performance standards for antimicrobial susceptibility testing for bacteria isolated from animals. 12th informational supplement, M100-S12. Wayne, PA: NCCLS. approved standard 2nd edition.

O'Donnell, E.T. 1995. The incidence of Salmonella and Listeria in raw milk from farm bulk tanks in England and Wales. J. Soc. Dairy Technol., 18: 2529.

OIE (world organization for animal health) terrestrial manual, 2013. chapter 1: collection, submission and storage of diagnostic specimens.

OXOID, manual, 2015. Culture media, ingredients and other laboratory Services. 11th edition Published by Oxoid LTD London.

Pantoja, J.C.F., Rodrigues, A.C.O., Hulland, 
C., Reinemann D.J., Ruegg, P.L. 2012. Investigating Contamination of Bulk Tank Milk with $L$. monocytogenes on a Dairy Farm. Food Protection Trends, Vol. 32, No. 9, pp. 512-521.

Radostitis, O.M., Gay, C.C., Hinchcliff, K.W., Constable, P.D. 2007. Vet. Medi., A textbook of the diseases of cattle, horses, sheep, pigs and goats, $10^{\text {th }}$ ed. W. B. Saunders, Edinburgh.

Rafie, S., Mojtaba, R., Mohsen, P.D., Amir, M.S. 2013. Prevalence of Listeria species in raw milk in Esfahan Province, Iran. African. J. Microbiol. Res., Vol. 7(19), pp. 2057-2060.

Rajala-Schultz, P.J., Smith, K.L., Hogan, J.S., Love, B.C. 2004. Antimicrobial susceptibility of mastitis pathogens from first lactation and older cows. Vet. Microbiol., 102: 33-42.

Rendos, J.J., Eberhat, R.J., Kesler, E.M. 1975. Microbiological populations of teat ends of dairy cows and bedding materials. J. Dairy Sci., 58(10): 1492:1500.

Riedo, F.X., Pinner, R.W., Tosca, M.L., Cartter, M.L., Graves, L.M., Reeves, M.W., Weaver, R.E., Plikaytis, B.D., Broome, C.V. 1994. A point source foodborne listeriosis outbreak: documented incubation period and possible mild illness. J. Infect. Dis., 70: 693-696.

Roberts, D., Hooper, W., Greenwood, M. 1995. Prac. Food Microbiol., London: Public Health Laboratory Service, pp. 146-149.

Rota, C., Yanguela, J., Blanco, D., Carramilana, J.J., Arino, A., Herrera, A. 1996. High prevalence of multiple resistances to antibiotics in 144 Listeria isolates from Spanish dairy and meat products. J. Food Prot., 59: 938-943.

Ryser, E. T. 2001. Public health concerns, pp. 397-545. In E.H. Smith and J.L. Steele (ed.). Appl. Dairy Microbiol., 2nd ed. Marcel Dekker, Inc., New York.

Ryser, E.T., Marth, E. 2007. Listeria, Listeriosis and Food Safety, 3rd edition, Taylor and Francis, Boca Raton, FL.

Salyers, A.A., Whitt. D.D. 2002. Listeria monocytogenes, A Doubly Motile Pathogen. In: Bacterial Pathogenesis, A Molecular Approach, 2nd ed. ASM Press: Washington, D.C.

Sambrook, J., Fritscgh, E.F., Mentiates. 1989. Molecular coloning. A laboratory manual. $2^{\text {rd }}$ edition, Cold spring Harbor Laboratotry press, New York.

Sato, K., Bennedsgaard, T.W., Bartlett, P.C., Erskine, R.J., Kaneene, J.B. 2004. Comparison of antimicrobial susceptibility of Staphylococcus aureus isolated from bulk tank milk in organic and conventional dairy herds in the Midwestern United States and Denmark. J. Food Prot., 67(6): 11041110.

Slade, P., Collins-Thompson, D. 1990. Listeria, plasmids, antibiotic resistance and food. Lancet, 336: 1004-1005.

Srividya, Y., Kingston, J., Murali, H.S., Batra, H.V. 2013. Rapid and concurrent detection of listeria species by multiplex PCR. Int. J. Pharm. Bio. Sci., 4(1): 106 - 116.

Steele, M.L., McNab, W.B., Poppe, C., Griffiths, M.W. 1997. Survey on Ontario bulk tank raw milk for foodborne pathogens. J. Food Prot., 60: 1341-1346.

Tikofsky, L.L., Barlow, J.W., Santisteban, C., Schukken, Y.H. 2003. A comparison of antimicrobial susceptibility patterns for Staphylococcus aureus in organic and conventional dairy herds. Micro Drug Resistance Mech. Epi. Dis., 9(1): 3945. 
Ueno, H., Yokota, K., Arai1, T., Muramatsu, Y., Taniyama, H., Iida, T., Morita, C. 1996. The Prevalence of Listeria monocytogenes in the Environment of Dairy Farms. Microbiol. Immunol., 40(2): 121-124.

Van Kessel, J.S., Karns, J.S., Gorski, L., McCluskey, B.J., Perdue, M.L. 2004. Prevalence of salmonellae, Listeria monocytogenes, and fecal coliforms in bulk tank milk on U.S. dairies. J. Dairy Sci., 87: 2822-2830.

Waak, E., Tham, W., Danielsson-Tham, M.L. 2002. Prevalence and fingerprinting of Listeria monocytogenes strains isolated from raw whole milk in farm bulk tanks and in dairy plant receiving tanks. Appl. Environ. Microbiol., 68: 3366-3370.

Winter, P., Schilcher, F., Bago, Z., Schoder, D., Egerbacher, M., Baumgartner, W., Wagner, M. 2004. Clinical and histopathological aspects of naturally occurring mastitis caused by Listeria monocytogenes in cattle and ewes. J. Vet. Med. B. Infect. Dis. Vet. Public Health, 51: 176-179.

Wong, A.C.L. 1998. Biofilms in food processing environments. J. Dairy Sci., 81: 2765-2770.

\section{How to cite this article:}

Dabash, S.M., Saudi, A.M., El Essawy, H. and Hamouda, R.H. 2016. Application of Specific Chromogenic Media and Api Technique for Rapid Confirmation of Listeria monocytogenes in Bulk Tank Milk and Dairy Farms Environment. Int.J.Curr.Microbiol.App.Sci. 5(3): 144-158. doi: http://dx.doi.org/10.20546/ijcmas.2016.503.020 